\title{
Karkearehun jakomenetelmien fyysinen kuormittavuus, työturvallisuus ja taloudellinen kannattavuus
}

\author{
Janne Karttunen ja Mika Peltonen \\ Työtehoseura, Maatalousosasto, PL 13, 05201 Rajamäki \\ Sähköposti: janne.karttunen@tts.fi, mika.peltonen@tts.fi
}

\section{Johdanto}

Vuonna 1998 tapahtui suomalaisilla maatiloilla hieman alle 8000 raportoitua työtapaturmaa. Niistä lähes puolet sattui kotieläintenhoitotöissä ja näistä huomattava osa nimenomaan nautakarjan ruokintatöissä (taulukko 1). Säilörehun irrotus ja siirto välivarastosta navettaan sekä sen jakaminen naudoille on navettatöistä fyysisesti kuormittavinta (Kivikko ja Viitaniemi 1995). Toistuvat yksipuoliset liikkeet olivat suurin yksittäinen ammattitautien aiheuttajaryhmä suomalaisilla maanviljelijöillä vuonna 1998 (Maatalousyrittäjien eläkelaitos 1999). Pinzken (1996) tutkimusaineiston mukaan yli 80 prosentilla ruotsalaisista maidontuottajista oli ollut lähimmän vuoden aikana oireita tuki- ja liikuntaelimissä. Maidontuottajien mukaan säilörehuruokinta ja lypsytyö kuormittivat heitä eniten maatilan töissä. Tuotantoaan laajentavalle maidontuotantotilalle eivät karkearehun jakoon sovellu perinteiset - edelleen hyvin yleiset - käsityövaltaiset ja ergonomisesti sekä työturvallisuusmielessä riskialttiit menetelmät.

Tässä Maatalousyrittäjien eläkelaitoksen työturvallisuusapurahalla tehdyssä tutkimuksessa kartoitettiin maidontuotantotiloilla yleisesti käytettävien karkearehun jakomenetelmien - mukaan lukien seosrehuruokinta - fyysinen kuormittavuus, työturvallisuusriskit sekä koneinvestointien taloudellinen kannattavuus. Tavoitteena oli määrittää, mitkä ovat sopivia työmenetelmiä ja -välineitä kuhunkin työvaiheeseen työtekniset ja työturvallisuusnäkökohdat huomioon ottaen.

Taulukko1. Karjanhoitotöissä sattuneet työtapaturmat ja niiden jakaantuminen eri työvaiheiden kesken vuonna 1998 (Maatalousyrittäjien eläkelaitos 1999).

\begin{tabular}{|c|c|c|c|}
\hline \multirow{2}{*}{\multicolumn{2}{|c|}{$\frac{\text { Työvaihe }}{\text { Nautakarjan ruokinta }}$}} & $\mathrm{kpl}$ & $\underline{\%}$ \\
\hline & & 869 & 23 \\
\hline Rehun irrotus & 42 & & \\
\hline Rehun kuljetus & 523 & & \\
\hline Varsinainen ruokinta & 304 & & \\
\hline Lypsy & & 713 & 19 \\
\hline Nautojen kuljetus ja siirto & & 634 & 17 \\
\hline Lannanpoisto ja kuivitus & & 215 & 6 \\
\hline Muut nautakarjan hoitotyöt & & 680 & 18 \\
\hline Muiden tuotantoeläinten hoitotyöt (siat, hevoset, siipikarja jne.) & & 624 & 17 \\
\hline Yhteensä & & 3735 & 100 \\
\hline
\end{tabular}

\section{Aineisto ja menetelmät}

Maatalousyrittäjien eläkelaitoksen tapaturmatilastoista hankittiin pohjatietoa nautakarjatalouden ruokintatöissä sattuneista raportoiduista tapaturmista ja niiden aiheuttajista.

Tutkimuksessa vierailtiin yhdeksällä eri karkearehun jakomenetelmää edustavalla maidontuotantotilalla. Kullakin maitotilalla selvitettiin työntekijän fyysinen kuormitus karkearehun siirrossa ja jaossa seuraavia menetelmiä käyttäen:

RPE (Rating of Perceived Exertion) -menetelmällä selvitettiin työntekijän kokeman kuormituksen suuruus. Menetelmässä työntekijältä kysytään: "Kuinka kovasti tunnet työskenteleväsi tällä hetkellä?". Mitta-asteikkona on Borgin RPE-asteikko, jossa on lukuarvot 6 - 20. Arvot vastaavat työntekijän pulssia lepopulssista 60 äärimmäiseen rasituspulssiin 200 asti. (Borg 1986).

Ergoprofiilimenetelmässä työntekijä itse merkitsi työsuorituksen jälkeen lomakkeen ihmishahmoon kehonosiensa (17 eri kehonosa-aluetta) kuormittuneisuustuntemuksensa kolmiportaisen asteikon mukaan. Arviot kootaan taulukkoon työn ergoprofiiliksi. (Määttä ym. 1983).

OWAS (Ovako Working Posture Analysing System) -menetelmällä selvitettiin eri työasentojen kuormittavuus. Menetelmässä työntekijän videoitu työsuoritus analysoidaan jälkeen päin työvaihe kerrallaan. Työntekijän työasennot voidaan jakaa 84 perustyyppityöasentoon. Kuormitusta lisäävä ulkopuolinen kuorma tai voiman tarve jaetaan kolmeen eri luokkaan. (Louhevaara \& Suurnäkki 1991). 
Työntekijän syketaajuus mitattiin karkearehun käsittelyn aikana ranteessa kannettavalla sykemittarilla. Sykedata siirrettiin tietokoneelle ja sitä verrattiin tutkimusten jälkeen OWAS- ja RPE -menetelmillä kerättyyn dataan.

Työajan menekki huomioitiin suhteessa eläinmäärään ja ruokinnassa käytettyyn rehumäärään. Myös rehuketjun laitteiden hankinta- ja asennuskustannuksia arvioitiin samoin perustein. Lisäksi kartoitettiin kullekin menetelmälle ominaisia työturvallisuusriskejä.

\section{Tulokset ja tulosten tarkastelu}

Taulukossa 2 on suuntaa antava vertailu tutkituista karkearehun jakomenetelmistä. Menetelmiä vertailtaessa on ehdottomasti huomioitava niiden vaatima rehunkäsittelyketju kokonaisuudessaan. Tulosten mukaan yli 40 lypsylehmän - lisäksi uudistamiseen tarvittava määrä nuorkarjaa - ruokinta on sujuvaa mattoruokkijaa (kuva 1) ja ketjuruokintapöytää (kuva 2) käyttäen. Ne soveltuvat myös seosrehun jakamiseen ja toimivat myös kylmäpihatossa. Menetelmät ovat hankinta- ja asennushinnoiltaan edullisia verrattuna apevaunuun ja kiskoruokkijaan (Karttunen \& Peltonen 2001).

Hankinta- ja asennushinnaltaan edellisiä kalliimman kiskoruokkijan (kuva 4) avulla kyetään ruokinta optimoimaan parsinavetassa em. järjestelmiä paremmin. Eräät kiskoruokkijamallit jakavat myös väkirehua. Em. menetelmillä voidaan jakaa rehut esimerkiksi 4 - 6 kertaa vuorokaudessa, kuten eräillä tutkimustiloilla tehtiin. (Karttunen \& Peltonen 2001). Koska edellä mainitut menetelmät eivät vaadi ruokintapöydällä ajamista ja vain hieman ruokintapöydällä liikkumista, on hygieniariski alhainen. Menetelmät vaativat - automatisoinnin tasosta ja käyttäjän ammattitaidosta riippuen - vain vähän tai ei ollenkaan fyysistä työtä, joten työturvallisuus- ja ergonomiataso on keskimäärin erinomainen.

Taulukko 2. Karkearehun eri levitysmenetelmien sopivuus vähintään 40 lypsylehmän karjan ruokintaan arvioituna eri muuttujien suhteen. Muuttujat: ergonomia (summa RPE-, ergoprofiili- ja OWASmenetelmistä sekä pulssista), päivittäinen tapaturmariski, hankinta- ja asennuskustannukset, päivittäisen fyysisen työn tarve/lehmä, hygieniariski sekä varajärjestelmien tarve (konerikon takia). Pisteytys: 1 - 5. Esimerkki: menetelmä vaatii melko runsaasti ergonomisesti huonoja työasentoja $=2$ tai häiriöttä toimiessaan menetelmän aiheuttamat työtapaturmariskit ovat olemattomat $=\mathbf{5}$.

\begin{tabular}{|c|c|c|c|c|c|c|c|}
\hline Menetelmä & $\begin{array}{l}\text { Ergono- } \\
\text { mia }\end{array}$ & $\begin{array}{l}\text { Päivittäi- } \\
\text { nen tapa- } \\
\text { turmariski }\end{array}$ & $\begin{array}{l}\text { Hankinta- } \\
\text { ja asen- } \\
\text { nuskus- } \\
\text { tannukset }\end{array}$ & $\begin{array}{c}\text { Fyysisen } \\
\text { työn } \\
\text { tarve/ } \\
\text { lehmä }\end{array}$ & $\begin{array}{l}\text { Hygienia- } \\
\text { riski }\end{array}$ & $\begin{array}{c}\text { Varajär- } \\
\text { jestelmien } \\
\text { tarve }^{5)}\end{array}$ & $\begin{array}{l}\text { Pisteet } \\
\text { yh- } \\
\text { teensä. } \\
\text { Max } \\
30\end{array}$ \\
\hline $\begin{array}{l}\text { 1. Käsikäyttöinen rehu- } \\
\text { hamsteri+käsin talikointia }{ }^{1)}\end{array}$ & 2 & 2 & 5 & 2 & 4 & 5 & 20 \\
\hline $\begin{array}{l}\text { 2. Pyöröpaalileikkuri + } \\
\text { käsin talikointia }{ }^{2)}\end{array}$ & 3 & 3 & 4 & 3 & 4 & 4 & 21 \\
\hline $\begin{array}{l}\text { 3. Lastaava ja ajettava re- } \\
\text { hunjakovaunu }\end{array}$ & 4 & 4 & 3 & 4 & 4 & 4 & 23 \\
\hline $\begin{array}{l}\text { 4. Vedettävä jakolava/ } \\
\text {-vaunu + käsin talikointia }{ }^{l)}\end{array}$ & 2 & 2 & 5 & 3 & 4 & 5 & 21 \\
\hline 5. Ketjuruokintapöytä ${ }^{3), 4)}$ & 5 & 5 & 4 & 5 & 5 & 3 & 27 \\
\hline $\begin{array}{l}\text { 6. Seosrehuvaunu, lastaus- } \\
\text { ja purkutyö }{ }^{3), 4)}\end{array}$ & 4 & 4 & 2 & 4 & 3 & 4 & 21 \\
\hline $\begin{array}{l}\text { 7. Ajettava pienkuormain + } \\
\text { käsin talikointia }{ }^{1)}\end{array}$ & 3 & 3 & 3 & 3 & 4 & 4 & 20 \\
\hline 8. Kiskoruokkija ${ }^{3), 4)}$ & 5 & 5 & 2 & 5 & 5 & 3 & 25 \\
\hline 9. Mattoruokkija ${ }^{3), 4)}$ & 5 & 5 & 3 & 5 & 5 & 4 & 27 \\
\hline
\end{tabular}

\footnotetext{
1) Levitysmenetelmä vaatii traktorin etukuormaimeen kiinnitettävän tai kolmipistekiinnitteisen rehuleikkurin, jolla rehukakut tuodaan navetan välivarastoon.

2) Ergonomia paranee ja fyysisen työn tarve vähenee, mutta hygieniariski sekä hankintahinta kasvavat, kun käytetään traktoriin kiinnitettävää pyöröpaalisilppuria ja yhdistelmällä ajetaan ruokintakäytävällä.

3) Menetelmä vaatii rehuleikkurin ja täyttöpöydän/seosrehuvaunun tai täyttöpurkaimella ja lietsolla varustetun rehutornin.

4) Menetelmä sopii/on tarkoitettu myös seosrehulle.

5) Muuttuja ei arvioi menetelmän altistavuutta työtapaturmille vaan konerikon riskiä ja haitan suuruutta .
} 
Rehunkäsittelyketjuista ergonomisesti suositeltavin on: rehutorni - täyttöpurkain - lietso - kiskoruokkija. Kiskoruokkija jakaa esikuivattua \& tarkkuussilputtua säilörehua sekä eräät mallit myös väkirehua. Häiriöttä toimiessaan tämän rehuketjun aiheuttama tapaturmariski on hyvin pieni. Kiskoruokkija, kuten myös mattoruokkija sekä ketjuruokintapöytä, sopivat kapeallekin ruokintapöydälle.

Edellä mainitut menetelmät vaativat toimivan täyttösysteemin, kuten apevaunun tai repijälaitteella varustetun täyttöpöydän, joka täytetään traktorikäyttöisellä rehuleikkurilla. Traktorin etukuormaimeen kiinnitettävää rehuleikkuria käytettäessä on työasento ergonomisempi ja työ turvallisempaa kuin takanostolaiteeseen kiinnitettävää rehuleikkuria käytettäessä.

Traktorilla vedettävä apevaunu (kuva 3) on tehokas ruokittaessa suuria, Kailan (1999) mukaan yli 50 lehmää, eläinmääriä. Vaunun hankintahinta on korkeahko. Apevaunua edullisemmat ajettavat jakovaunut sekä maatilalla monikäyttöiset pienkuormaimet ovat myös varteenotettavia vaihtoehtoja karkearehun levitykseen. Rehun irrotukseen tarvitaan näissäkin menetelmissä traktori ja rehuleikkuri.

Aikaisempia tutkimuksia karkearehun käsittelymenetelmistä on olemassa useita (esim. Kivikko ja Viitaniemi 1995, Kaila 1999). Tässä tutkimuksessa olivat ensimmäistä kertaa mukana maassamme vielä suhteellisen harvinaiset ketjuruokintapöytä sekä mattoruokkija. Nämä menetelmät sopivat erityisesti isoille maitotiloille, joiden lukumäärä on jatkuvassa kasvussa. Laajentavien maitotilojen työnkäytön ja työtä helpottavien menetelmien tutkiminen on tärkeää. Jatkossa olisi tutkittava lisää myös em. menetelmiä ja niiden vaatimia täyttöjärjestelmiä sekä varajärjestelmiä. Koska väkirehun merkitys nautojen ruokinnassa on kasvanut, on tutkittava täyttöjärjestelmien toimivuutta myös seosrehujen kanssa.

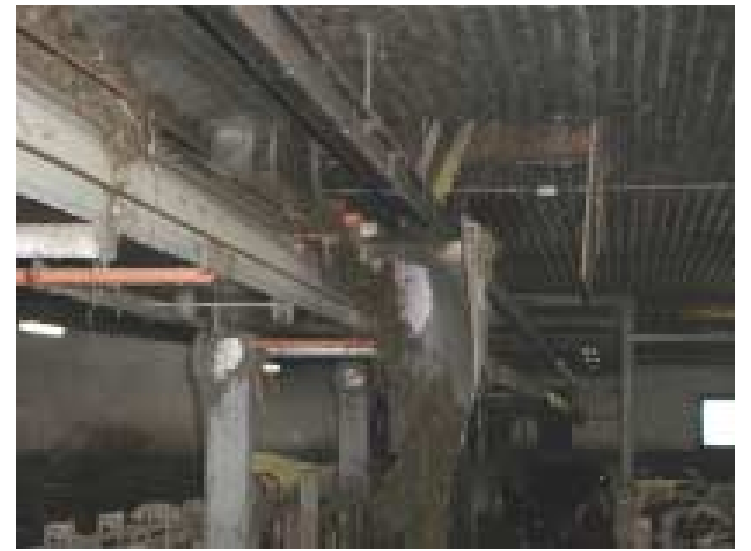

Kuva 1. Kattoon asennettava kevytrakenteinen, hygieeninen sekä edullinen mattoruokkija vaatii täyttöjärjestelmän. Se soveltuu myös seosrehun jakoon ja parsinavettaan. Ryhmäkohtainen ruokinta on mahdollista.

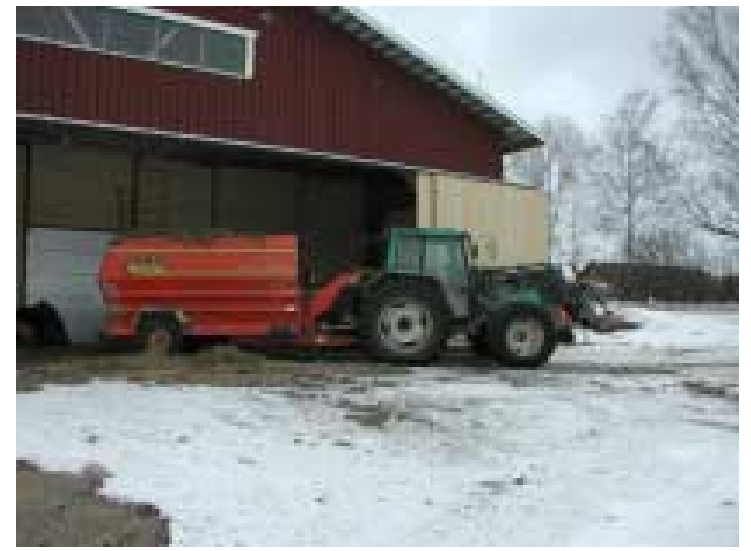

Kuva 3. Apevaunu vaatii min. $4 \mathrm{~m}$ leveän ruokintapöydän, mutta seosrehun sekoitus ja jako on nopeaa ja kevyttä työtä. Hygieniariski laskee, jos ruokintapöydällä ei ajeta. Vaunu sopii myös tilayhteistyöhön.

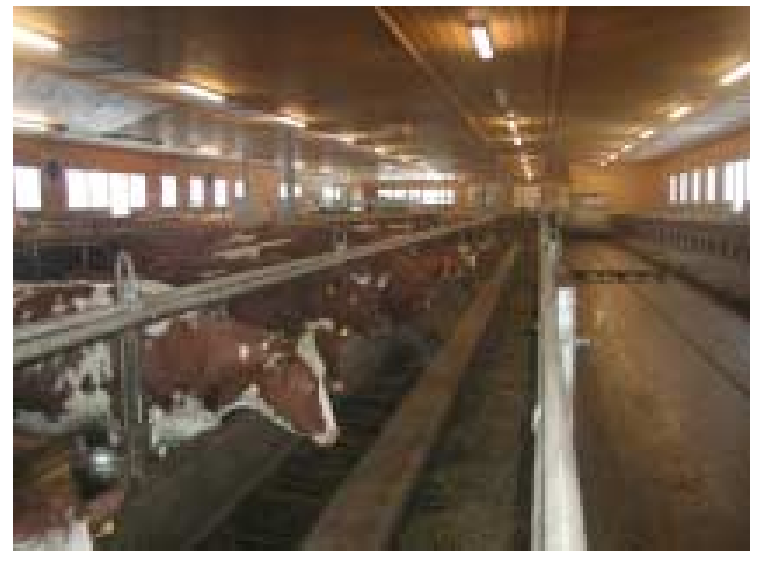

Kuva 2. Ketjuruokintapöytä säästää kallista lattiapinta-alaa uuteen pihattoon asennettuna. Täyttöjärjestelmän avulla jopa täysautomatisointi onnistuu. Hankinta- ja asennushinta on alhainen. Ryhmäkohtainen ruokinta on mahdollista.

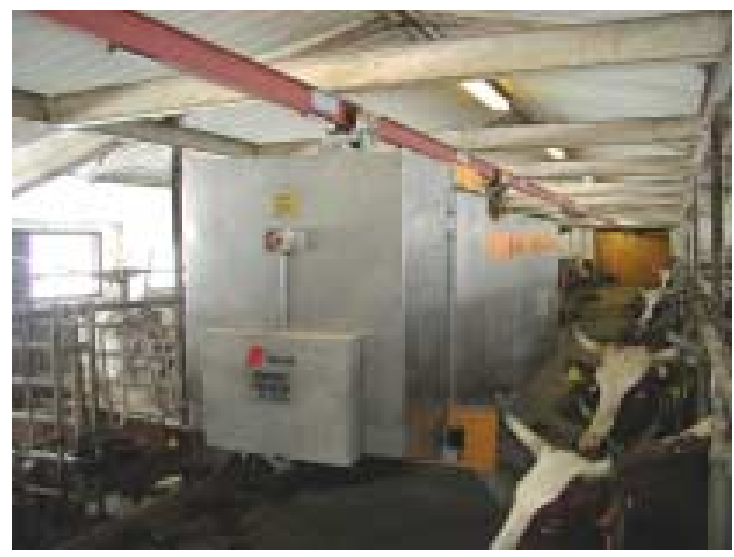

Kuva 4. Kiskoruokkija voi jakaa myös väkirehut yksilöllisesti. Ruokinnan optimointitaso on korkea ja ruokinnan hygieniariski on pieni. Laite sopii kapeahkollekin käytävälle. Hankinta- ja asennuskustannukset ovat korkeat: n. 25 - $35000 €$. 
Nyt tutkittiin tiettävästi kaikkia tällä hetkellä ja oletettavasti myös lähitulevaisuudessa Suomessa käytettäviä karkearehun käsittelymenetelmiä. Ne rehuketjun osat, joita tiloilla ei voitu tutkia, selvitettiin uusimpien kirjallisten lähteiden ja puhelinhaastattelujen perusteella. Näin toiminnalliset puutteet tutkimustilojen rehuketjuissa tai tutkijan/haastateltavien subjektiivisuus eivät päässeet heikentämään arviota kyseisestä menetelmästä. Tuloksia käytäntöön soveltamalla kyetään mm. vähentämään työn kuormittavuutta ja hygieniariskiä sekä parantamaan työturvallisuutta ja tuotannon kannattavuutta.

\section{Johtopäätökset}

Toiminnallinen suunnittelu on avainasemassa, kun pyritään tehostamaan karkearehuruokintaa. Suunnittelussa on huomioitava mm. navettatyyppi, ruokintaa varten käytettävissä oleva tila, navetan kantavat rakenteet ja nykyinen sekä suunniteltu karjakoko ja työvoima. Investoinnin takaisinmaksuaikaa silmällä pitäen on mietittävä, kuinka kauan aiotaan jatkaa maidontuotantoa. Lisäksi on huomioitava olemassa oleva konekanta, mahdollisuudet tilayhteistyöhön konehankinnoissa, säilörehun korjuu(tuoresäilötty vai esikuivattu \& tarkkuussilputtu) ja varastointitapa (torni, siilo, auma tai pyörö/kanttipaalit) sekä väkirehun käsittely. Väkirehun jako voidaan monissa tapauksissa yhdistää karkearehun jakoon. Seosrehuruokinta on myös varteenotettava vaihtoehto. Useat karkearehun jakolaitteet soveltuvat hyvin myös seosrehun jakoon sekä kylmäpihattoon.

Täyttölaitteen järkevällä sijoittamisella tuotantorakennukseen on suuri merkitys koko ruokintajärjestelmän toimivuudelle. Täyttölaite sekä varsinainen ruokintalaite voidaan monissa tapauksissa automatisoida täysin, jolloin päivittäinen työ on lähinnä järjestelmän toiminnan tarkkailua sekä ruokinnan optimointia. Automatisointi maksaa, mutta järjestelmien välillä on merkittäviä hintaeroja.

Koko karkearehun käsittelyketjua varastosta välivaraston kautta ruokintapöydälle on muistettava tarkastella. Kaikkien osien tulee niveltyä toisiinsa saumattomasti, jotta aikaansaadaan toimiva ruokintajärjestelmä. Toiminnalliset puutteet rehuketjussa voivat kasvattaa päivittäistä työmäärää, fyysistä rasitusta ja tapaturmariskiä.

Varajärjestelmien merkitys kasvaa automaation ja karjamäärän kasvun myötä. Jos ruokintalaite rikkoontuu, tulee olla etukäteen mietitty, miten suuri karjamäärä kyetään ruokkimaan ruokintalaitteen korjauksen aikana muuten kuin käsityönä. Myös sähkökatkoihin on varauduttava ja hankittava varavirtajärjestelmä tai vähintään ko. laitteiston kytkentävalmius. On laadittava kirjallinen suunnitelma, jossa on varaosatoimittajien ja korjausmiesten yhteystiedot, jotta myös lomittaja saa tilalle nopeasti apua.

Häiriötilanteiden merkitys työn sujuvuudelle ja työturvallisuudelle kasvaa, kun siirrytään runsaasti automatiikkaa sisältäviin ruokintalaitteisiin. Normaalisti toimiessaan ja ohjeiden mukaan käytettyinä laitteet ovat helppohoitoisia ja turvallisia. Häiriötilanteissa voi piillä mahdollisuus vakavaan työ-turvallisuusriskiin. Erityisesti tilapäinen työvoima, kuten lomittajat, on opetettava käyttämään ruokintalaitteita turvallisesti. Työtapaturmien varalle on laadittava kirjallinen toimintasuunnitelma.

\section{Kirjallisuus}

Borg, G. 1986. Psychophysical studies of effort and exertion. In: Borg, G. \& Ottoson, D. (ed.) The Perception of exertion in physical work. Wenner - Gren Int. Symposium Series volume 46. $346 \mathrm{~s}$.

Kaila, E. 1999. Lypsykarjan hoitotöiden koneellistaminen. Työtehoseuran maataloustiedote 506: 1 - 8.

Karttunen, J. \& Peltonen, M. 2001. The physical strain, occupational safety and profitability of different roughage distribution methods. Proc.from seminar 326. NJF. Production and utilization of silage. Lillehammer: 91 -96.

Kivikko, J. \& Viitaniemi, P. 1995. Automaattiset rehunjakolaitteet säästävät aikaa ja selkää. Työtehoseuran maataloustiedote 453: 1 - 6 .

Louhevaara,V. \& Suurnäkki, T. 1991. Työasentojen kuormituksen arviointi: OWAS-menetelmä. Työterveyslaitos. Työturvallisuuskeskus. Koulutusjulkaisu 11: 1 - 24 s.

Maatalousyrittäjien eläkelaitos. 1999. MATA-Tilastovuosi 1998.

Määttä, T., Saari, J. \& Mattila, M. 1983. Esimerkki fyysisen kuormituksen arvioimisesta ja lavannostimen käytöstä kuormituksen vähentäjänä. Työterveyslaitos. Ergonomiatiedote 4: 1 - 31.

Pinzke, S. 1996. Musculoskeletal disorders and methods for studying working postures in agriculture. Licentiate thesis. SLU. Institutionen för jordbrukets biosystem och teknologi. Rapport 107. 